\title{
Physical restraint in elderly in home care: a cross-sectional study
}

\author{
Contenção mecânica em idosos da atenção domiciliar: estudo transversal \\ Sujecion mecánico en personas mayores de cuidado en casa: estudio transversal
}

Cristiane da Silva Gabriel Capeletto $^{a}$ (1)
Rosimere Ferreira Santana
Lívia Maria da Silva Souza
Keila Mara Cassiano
Aa

\section{How to cite this article:} Capeletto CSG, Santana RF, Souza LMS, Cassiano KM, Carvalho ACS, Barros PFA. Physical restraint in elderly in home care: a cross-sectional study. Rev Gaúcha Enferm. 2021;42:e20190410. doi: https://doi.org/10.1590/19831447.2021.20190410
Universidade Federal Fluminense (UFF). Niterói, Rio de Janeiro, Brasil.

\section{ABSTRACT}

Objective: To estimate the prevalence of mechanical restraint and factors associated with its practice in elderly in Home Care. Methods: This was a cross-sectional study with 162 elderly randomly assigned to a home care program in Rio de Janeiro, from March 2018 to July 2018. Used as a technique for data collection and direct observation and structured interview of elderly clinical data. Data were analyzed descriptively and inferentially.

Results: There was a 13\% prevalence of mechanical restraint in elderly in home care. The most frequent restraints were the use of bandage, tissues and sheets in the arms/legs and chests of the elderly, and the justification for their use were control of aggressive behavior (28.6\%), prevention of falls (19\%) and protection (19\%). Of the total elderly participants, $42.9 \%$ remained contained for more than 24 hours, and in $85.7 \%$ of the cases, the individuals were confined to a room.

Conclusion: It is necessary to expand the training of formal and informal caregivers, recommending the rehabilitation of care practices that preserve the elderly's autonomy, giving them dignity, respecting gerontological and home care principles.

Keywords: Restraint, physical. House calls. Home health nursing. Geriatric nursing. Health of the elderly.

\section{RESUMO}

Objetivo: Estimar a prevalência da contenção mecânica e fatores associados à sua prática na Atenção Domiciliar.

Métodos: Estudo transversal, realizado com 162 idosos de um programa de atenção domiciliar no Rio de Janeiro, de março de 2018 a julho de 2018. Utilizada como técnica de coleta de dados a observação direta e entrevista estruturada.

Resultados: Encontrou-se uma prevalência de 13\% da contenção mecânica em idosos na Atenção domiciliar; mais frequente foi de membros e tronco, realizado com atadura, tecidos e lençol; justificativas do uso: controle da agressividade (28,6\%), prevenção de quedas (19\%) e proteção (19\%); houve associação das variáveis do perfil com o desfecho de contenção: rotina de dias alternados $(p-v a l o r=0,000)$, não deambulação ( $p$-valor $=0,020)$, restrição ao leito $(p$-valor $=0,000)$ e uso de cateter vesical de demora ( $p$-valor=0,006).

Conclusão: Destaca-se a necessidade de capacitação dos profissionais de saúde, cuidadores formais e informais, no sentido de desnaturalizar a prática da contenção no domicílio.

Palavras-chave: Restrição física. Visita domiciliar. Enfermagem domiciliar. Enfermagem geriátrica. Saúde do idoso.

\section{RESUMEN}

Objetivo: Estimar la prevalencia de la restricción mecánica y los factores asociados con su práctica en ancianos en Atención domiciliaria.

Métodos: Este fue un estudio transversal de 162 ancianos asignados aleatoriamente a un programa de atención domiciliaria en Río de Janeiro, sin período de marzo de 2018 a julio de 2018. Utilizado como técnica para la recopilación de datos y observación directa y entrevista estructurada de datos clínicos de ancianos. Los datos se analizaron de forma descriptiva e inferencial.

Resultados: Hubo una prevalencia de restricción mecánica del 13\% en los ancianos de la atención domiciliaria. Los más frecuentes fueron las extremidades y el tronco, realizados con vendas, tejidos y sábanas, y como justificación de su uso: control de la agresividad (28,6\%), prevención contra caídas (19\%) y protección (19\%). De los participantes de edad avanzada, el 42,9\% permanece contenido durante más de 24 horas, en el $85,7 \%$ de los casos, restringido en una habitación individual.

Conclusión: Es necesario ampliar la capacitación de los cuidadores formales e informales, recomendando prácticas de atención de rehabilitación que preserven la autonomía de los ancianos, dándoles dignidad, respetando los principios gerontológicos y de atención domiciliaria.

Palabras clave: Restricción física. Visita domiciliaria. Cuidados de enfermería en el hogar. Enfermería geriátrica. Salud del anciano. 


\section{口INTRODUCTION}

The rapid aging of the world's population associated with the rising costs of health care and the constant search for well-being, quality of life and humanized care motivated the expansion of Home Care $(\mathrm{HC})^{(1-2)}$. This is a low-cost health care modality aimed to promote integrated care, deinstitutionalization, reduction of costs and long-term nursing homes ${ }^{(1-5)}$.

In home care, the family is the main link in the implementation of residential care ${ }^{(4)}$, especially in the AD1 modality, which is intended for patients who have difficulties to get to the health service, patients with controlled comorbidities who need less intensive care that may include follow-up after hospital discharge. AD1 is a very comprehensive home care network, responsible for almost $70 \%$ of the cases $^{(5)}$. It is precisely during the process of deinstitutionalization and migration to home care that family members or caregivers of patients sometimes use inadequate methods and make changes to care techniques and practices adopted by hospitals ${ }^{(4)}$. One modification detected in home care is the practice of restraint.

Restraint can be classified into four subtypes: physical, mechanical, chemical or pharmacological, and environmental. The health professional body is used to restrict the patient, either for a while, or to support a mechanical measure to be applied. Mechanical restraint is defined as the use of material or equipment attached to or adjacent to the individual's body, which cannot be removed and restricts freedom of movement or normal access to the body. Chemical restraint is the use of a drug or medication to control the patient's behavior or restrict freedom of movement, and is not a standard treatment for the patient's condition. Environmental restraint, which blocks someone inside a ward or room, is also a measure for restricting freedom, and it is commonly used in patients who walk, to prevent the circulation of elderly in spaces of common or domestic use, with removal of locks and use of electronic devices for locking doors and windows.

However, the most well-known and described restraint is mechanical restraint, which, as explained earlier, concerns the use of a device that limits a person's ability to get up and move, such as: vests, abdominal straps, wrist or ankle immobilizers, side rails, geriatric or reclining chairs with seat belts, gauze or bandages, abdominal straps, bed restraints, pelvic fixation strap, wheelchair table $e^{(2,3-7)}$.

The emphasis on mechanical restraint can be justified both by direct observation of studies on this subtype, but also because the scientific literature describes the deleterious consequences of this practice for the patients and its relationship with serious adverse events, such as: diffuse injuries to the body; fractures; ischemic injuries to the hands and arms; contusion; dislocation of limbs; decreased physical mobility, increased agitation; delirium; pressure ulcer; double incontinence; hip fractures; malnutrition; reduced muscle strength and balance; severe head injuries, fractures and death from asphyxia ${ }^{(7-13)}$.

There are only three prevalence studies in home care and they were conducted in Netherlands, Belgium and Japan. These studies found prevalence rates ranging from 20 to $40 \%$. Such variation is justified because bedside rails were considered mechanical restraint mechanisms. The Dutch study, for example, revealed that side rails are the most common restraint for elderly in home care (71.8\%), followed by door locking to prevent exit (37.7\%) and little use of mechanical restraint with belts and straps $(1.9 \%)^{(13-16)}$.

Thus, the understanding of restraint and its relationship with serious adverse events is still unknown to most nurses and formal and informal caregivers. Therefore, there is strong evidence that the unpreparedness of health professionals can result in little guidance on alternatives to the use of restraint for home caregivers, increasing the exposure of elderly patients to restraint measures ${ }^{(13,15-16)}$.

It should be stressed that mechanical restraint can only be used in Brazil under the supervision of a nurse, and as a last resort to prevent immediate or imminent risk to the life of the patient. Thus, Resolution 427/2012, of the Federal Nursing Council (COFEN), established interventions and care that must be provided in the case of use of mechanical restraint ${ }^{(17)}$. If these measures are necessary, the patient must be monitored by vital signs measurements, assessment of the level of consciousness, skin color and circulation in the restricted limbs. Elderly patients deserve more attention in these cases, as there must be more rigorous monitoring, due to the risk of these individuals developing delirium and the risks associated with mechanical restraint ${ }^{(17)}$.

Therefore, it is necessary to contextualize the practice of mechanical restraint in the home care environment, modality AD1 in Brazil, as, so far, studies on this topic have not yet been published in the country. Such contextualization can help to understand the use of these measures and associated factors, establish public policies for the training of health teams, interventions and further studies to monitor the prevalence rates. Therefore, the present study aimed to 
estimate the prevalence of mechanical restraint and factors associated with its practice in Home Care.

\section{METHOD}

This is a cross-sectional, observational study with a quantitative approach with elderly individuals from a Home Care program, AD1 modality, in the State of Rio de Janeiro, conducted from March to July 2018.

The population of interest was composed of 280 elderly individuals registered in the home care program. As it is impossible to conduct a study with the entire population, a sample representative of this universe was randomly selected. Considering the main objective of the study to estimate a $\mathrm{P}$ prevalence rate, according to authors, the minimum sample size $(n)^{(17)}$, for a maximum margin of error $e$, with correction for population size $N$, is defined by the following formula:

$$
n=\frac{z_{\alpha / 2}^{2} N p(1-p)}{(N-1) e^{2}+z_{\alpha / 2}^{2} p(1-p)}
$$

Thus, the minimum sample size estimated was $162 \mathrm{el}-$ derly people. For this sample size, the errors were fixed at a maximum of $5 \%$ and at any estimated proportion to a 95\% confidence level. The inclusion criteria were patients in home care, over 60 years old, who had family members/ caregivers at the time of data collection and who agreed to participate in the study.

The 162 elderly people were randomly selected. The selection was based on the general record of patient care and the schedule of the health service. The demand for patients and the scheduling of interviews were made by the Home Care team, without interference from the researcher. On the day scheduled for the interview, the research nurse was instructed to carry out the home visit. This routine was repeated until the minimum necessary sample size was obtained.

Direct observation and structured interviews were used in data collection. The interviews contained information about the caregiver, restraint practice and clinical data of the elderly. The form was filled out after the visiting nurse approached the patient during routine home visits. Upon entering the patient's residence, the nurse starts the process of observation of the place, provides care to the patient during the appointment and uses the form to collect relevant data, during the time usually devoted to care to the family, the patient and the caregiver. The average duration of the observation and completion of the forms was 35 minutes. As soon as data was collected and the forms were completed), family members/caregivers were invited to participate in the study and instructed to sign the Informed Consent Term, as this is an ethical and legal requirement for this type of research. Restrained elderly and their caregivers (family members or not) were advised on alternatives to restraint measures and on care to be delivered to the elderly.

The study variables were occurrence of restraint, gender age (years), degree of dependency of the elderly (the Katz Activities of Daily Living Scale (ADL), cognition (Mini Mental State Examination - MMSE), occurrence of pressure ulcer or skin tears, diagnoses, type of caregiver, length of time in the program, use of psychotropic drugs, duration of elderly restraint.

Based on the collected data, a database was built using Microsoft Excel ${ }^{\circledast} 2010$ software for evaluation using the SPSS program (Statistical Package for the Social Science), version 22.0. For the characterization of the sample using descriptive analysis of the behavior of the variables, data was summarized through the calculation of descriptive statistics (mean, median, minimum, maximum, standard deviation, variance, measurements of interest, such as the percentage of restrained elderly people), graphs, simple frequency distributions and in cross-tabulations.

In Inferential Analysis, the proportions of interest were also estimated by the confidence interval for the proportions. The significance of the association between two qualitative variables was investigated by chi-square test and, when this proved inconclusive, Fisher's exact test was applied, when appropriate. In Inferential Analysis of Quantitative Variables, the hypothesis of normality of the distribution was verified by Kolmogorov-Smirnov and Shapiro-Wilk tests. When the hypothesis of normal distribution was not rejected in the groups, comparison of two independent groups was made with Student's t-test. The equality of variances required to perform Student's t-test without correction was assessed by Levene's test. When the hypothesis of normality of the distribution was rejected for any of the groups, comparison of the two groups was made using non-parametric Mann-Whitney test.

The ethical principles of Research with Human Beings were observed according to Resolution 466/12 and the study was approved by the Research Ethics Committee of the institution on March 9, 2018 under number 2,730,357 and of the co-participant on June 22, 2018 under Protocol no $2,886.773$. 


\section{RESULTS}

\section{Type and prevalence of restraint}

Of the 162 elderly investigated, 21 elderly were in mechanical restraint. Based on these data, it is estimated that the prevalence of physical restraint among the elderly in home care was $13.0 \%$, with a forecast error of $5.2 \%$ at the $95 \%$ confidence level, that is, $7.8 \%$ to $18.2 \%$. Table 1 shows the frequency distributions of the variables that characterize restraint of elderly in home care.

Therefore, the most frequent restraint was the one that restrained limbs and chest performed with bandages, tissues and sheets; and the most frequent justification for their use were control of aggressive behavior and agitation, and prevention of falls, and the most serious aspect related to this restraint is that the elderly are restrained for more than 12 hours. It is worth noting that in addition to the high prevalence of mechanical restraint, environmental restraint was also found in $85.7 \%$ of the cases, that is, in addition to being mechanically restrained, most elderly did not have access to the other rooms of the house or to external activities. It was also observed that most of the restraints (81.0\%) were decided by the family caregiver. In other words, the decision was made empirically, as in the hospital model, based on experiences of previous hospitalizations, without the support of the professional technical support team.

\section{Profile of the elderly submitted to mechanical restraint and their caregivers}

Table 2 highlights the characteristics of the participants, with data on restrained and unrestrained elderly.

It was found that only care on alternate days was significantly different between the two groups of restrained and unrestrained elderly, and this care was performed by formal caregivers, who had an employment contract.

Table 1 - Frequencies of mechanical restraint variables. RJ, 2018.

\begin{tabular}{ll} 
Characteristics of the restraint & \multicolumn{2}{c}{ Sample } \\
\cline { 2 - 3 } & $\mathbf{n}$
\end{tabular}

\section{Type of Mechanical Restraint}

$\begin{array}{llr}\text { Bandage } & 08 & 38.1 \\ \text { Tissue } & 05 & 23.8 \\ \text { Sheet } & 05 & 23.8 \\ \text { Rail } & 03 & 14.3 \\ \text { Justification for restraint } & & 28.6 \\ \text { Aggressiveness } & 06 & 19.0 \\ \text { Agitation } & 04 & 28.6 \\ \text { Risk of falls } & 06 & 4.8 \\ \text { Lack of caregivers } & 01 & 4.8\end{array}$

\section{Duration of restraint}

$\begin{array}{lll}8 \text { hours a day (morning) } & 01 & 4.8\end{array}$

8 hours a day (night) 19.0

22 hours a day (No restraint during lunch) $\quad 01 \quad 4.8$

22 hours a day (No restraint during bath) $\quad 0628.6$

$\begin{array}{lll}24 \text { hours a day } & 09 & 42.9\end{array}$

Source: Research data, 2018. 
Table 2 - Frequencies of the characteristics of restrained and unrestrained elderly. Rio de Janeiro, 2018

\begin{tabular}{cccccccc} 
& \multicolumn{2}{c}{ Unrestrained } & \multicolumn{2}{c}{ Restrained } & & \multicolumn{2}{c}{ Global } \\
\cline { 2 - 6 } Variable & F & $\%$ & f & $\%$ & f & $\%$ & p-value
\end{tabular}

\section{Gender}

Female

Male

Age

60-68 years

69-76 years

77-84 years

85-91 years

\section{Caregiver}

Family member $\quad 96$

Formal Caregiver $\quad 27$

Nursing Technician $\quad 11$

Nursing Assistant $\quad 18$

\section{Care Routine}

Morning

24

09

13

02

36

11

96

On alternate Days

Every day
60.3

13

39.7

25.5

38.3

28.4

7.8

$68.1 \quad 10$

07

19.1

7.8

04

12.8

05

17.0

09

6.4

01

9.2

03
$1.4 \quad 05$

$67.4 \quad 10$
61.9

38.1

23.9

33.3

33.3

9.5

47.6

33.3

19.0

23.8

28.6

4.8

14.3

23.8

47.6

28.6

19.0

14.3

9.5

9.5

14.3

4.8

4.3

01

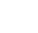

105

64.8

0.077

0.887

37.6

25.4

37.6

29.0

$0.276^{(a)}$

8.0

65.4

0.066

21.0

$0.154^{(b)}$

9.3

$0.109^{(b)}$

14.2

$0.185^{(b)}$

Duration of Integrated Home Care Service (SIAD)

Sourc: Research data, 2018

${ }^{(a)}$ Mann Whitney Test ${ }^{\left({ }^{b}\right)}$ Fisher's Exact Test 


\section{Characteristics of the environment and functional capacity of the elderly submitted to Mechanical Restraint}

On the other hand, regarding the characteristics of the residence and the demand for care, the following characteristics were observed: adequate accessibility of the house (64.2\%); wheelchair use (25.3\%); elderly confined to bed, bedridden (25.9\%); use of 01 psychotropic medication (40.1\%); gastrostomy use (18.6\%); use of permanent bladder catheterization (4.3\%); adequate activity plan (44.4\%).

Distribution of the KATZ score, which assesses the functional capacity of the elderly, ranged from 0 to 6 , resulting in an average of 3.7, median of 3.0. Mann-Whitney test showed a significant difference between the KATZ scores of unrestrained and restrained elderly ( $p$-value $=0.000$ ), with lower values for the restrained elderly, who are therefore more dependent.

As for the Mini Mental State Examination (MMSE), it revealed a variation from 0 to 20, which resulted in an average of 4.2, median of 1.0, with coefficient of variation equal to 1.3. Mann-Whitney test showed a significant difference between
MMSE scores ( $p$-value $=0.000$ ), which were lower in the group of restrained elderly.

Another important difference found in the demand for care and in the profile of the two groups was the occurrence of skin tears and pressure ulcers tear, which are shown in Figure 1.

The difference was statistically significant ( $p$-value $=$ 0.001 of Fisher's exact test). There was an odds ratio equal to 9.0 with a confidence interval equal to $(2.6 ; 31.4)$. Thus, it is estimated that the chance of a restrained elderly person having Skin Tears is 9 times higher than the chance of an unrestrained elderly person having skin Tears.

Table 3 highlights the types of Pressure Ulcer that, although not statistically significant, revealed clinical differences in the elderly submitted to restraint.

\section{Association of variables with mechanical restraint}

Table 4 shows the analysis of the association of the profile variables with the restraint outcome, namely: Routine of alternate days ( $p$-value $=0.000$ of the chi-square test),

Table 3 - Description of Pressure Ulcer Cases in restrained and unrestrained elderly. Rio de Janeiro, 2018

\begin{tabular}{|c|c|c|c|c|}
\hline Group & Site of Injury & Type of Restraint & $\begin{array}{l}\text { Duration of restraint } \\
\text { of elderly patients }\end{array}$ & Number of Cases \\
\hline \multirow{5}{*}{ Unrestrained } & Calcaneus & - & - & 05 \\
\hline & Knee & - & - & 01 \\
\hline & Occipital bone & - & - & 01 \\
\hline & Sacrum & - & - & 04 \\
\hline & Trochanter & - & - & 01 \\
\hline \multirow{9}{*}{ Restrained } & Calcaneus & Bandage & Night & 01 \\
\hline & & Bandage & No restraint during bath & 01 \\
\hline & & Tissue Sheet & Night & 01 \\
\hline & Shoulder blade & Bandage & 24 hours & 01 \\
\hline & Sacrum & Bandage & 24 hours & 01 \\
\hline & & Sheet & Morning & 01 \\
\hline & & Tissue & No restraint during bath & 02 \\
\hline & Trochanter & Bandage & 24 hours & 01 \\
\hline & & Tissue & No restraint during bath & 01 \\
\hline
\end{tabular}

Source: Research data, 2018 
Table 4 - Analysis of the association of variables of the elderly profile with the restraint outcome. Rio de Janeiro, 2018

\begin{tabular}{|c|c|c|c|c|c|c|c|}
\hline \multirow[t]{2}{*}{ Variable } & \multicolumn{2}{|c|}{$\begin{array}{l}\text { Prevalence of } \\
\text { restraint when the } \\
\text { factor is not present }\end{array}$} & \multicolumn{2}{|c|}{$\begin{array}{l}\text { Prevalence of } \\
\text { restraint when the } \\
\text { factor is present }\end{array}$} & \multirow[t]{2}{*}{ p-value } & \multirow[t]{2}{*}{ OR } & \multirow[t]{2}{*}{$\begin{array}{c}\text { Cl of } \\
\text { the OR }\end{array}$} \\
\hline & $f$ & $\%$ & f & $\%$ & & & \\
\hline Male gender & $13 / 98$ & 13.3 & $8 / 64$ & 12.5 & 0.887 & 0.9 & $0.4-2.4$ \\
\hline \multicolumn{8}{|l|}{ Caregiver } \\
\hline Family member & $11 / 56$ & 19.6 & $10 / 106$ & 9.4 & 0.066 & 0.4 & $0.2-1.1$ \\
\hline Formal caregiver & $14 / 128$ & 10.9 & $7 / 34$ & 20.6 & $0.154^{(b)}$ & 2.1 & $0.8-5.7$ \\
\hline Nursing Technician & $17 / 147$ & 11.6 & $4 / 15$ & 26.7 & $0.109^{(b)}$ & 2.8 & $0.8-9.7$ \\
\hline Nursing Assistant & $16 / 139$ & 11.5 & $5 / 23$ & 21.7 & $0.185^{(b)}$ & 2.1 & $0.7-6.5$ \\
\hline \multicolumn{8}{|l|}{ Caregiver's routine } \\
\hline Morning & 15/132 & 11.4 & $6 / 30$ & 20.0 & $0.229^{(b)}$ & 2.0 & $0.7-5.5$ \\
\hline Afternoon & $20 / 152$ & 13.2 & $1 / 10$ & 10.0 & $1.000^{(b)}$ & 0.7 & $0.1-6.1$ \\
\hline Night & $18 / 146$ & 12.3 & $3 / 16$ & 18.8 & 0.468 & 1.6 & $0.4-6.3$ \\
\hline On alternate days & $16 / 155$ & 10.3 & $5 / 7$ & 71.4 & 0.000 & 21.7 & $3.9-121$ \\
\hline Every day & $11 / 57$ & 19.3 & 10/105 & 9.5 & 0.077 & 0,4 & $0.2-1,1$ \\
\hline Walks & $17 / 79$ & 21.5 & $4 / 83$ & 4.8 & 0.002 & 05 & $0.1-0.6$ \\
\hline Adequate Accessibility & $10 / 58$ & 17.2 & $11 / 104$ & 10.6 & 0.226 & 0.6 & $0.2-1.4$ \\
\hline Wheelchair & $18 / 121$ & 14.9 & $3 / 41$ & 7.3 & 0.213 & 0.5 & $0.1-2.6$ \\
\hline Bed Restriction & $8 / 120$ & 6.7 & $13 / 42$ & 31.0 & 0.000 & 6.3 & $2.4-16.6$ \\
\hline $\begin{array}{l}\text { Permanent } \\
\text { Bladder Catheterization }\end{array}$ & $17 / 155$ & 11.0 & $4 / 7$ & 57.1 & $0.006^{(b)}$ & 10.8 & $2.2-52.5$ \\
\hline Gastrostomy & 14/131 & 10,7 & $7 / 30$ & 23.3 & $0.075^{(b)}$ & 2.5 & $0.9-7.0$ \\
\hline
\end{tabular}

Source: Research data, 2018.

(b) Fisher's Exact Test

not walking ( $p$-value $=0.020$ of the chi-square test), bed restriction ( $p$-value $=0.000$ of the chi-square test) and use of permanent bladder catheterization ( $p$-value $=0.006$ of Fisher's exact test).

However, it is estimated that the chance that an elderly person who has a caregiver on alternate days being subjected to restraint is 21.7 times greater than the chance of an elderly person who walks; the chance that an elderly person confined to bed is subjected to restraint is 6.3 times greater; and the chance that an elderly person using permanent bladder catheterization is restrained is 10.8 times greater.

\section{DISCUSSION}

The main finding of this study is the description of the $13 \%$ prevalence of mechanical restraint in elderly in home care, which is unprecedented in the health scenario and in Brazil. These data corroborate studies carried out in Japan, Belgium and the Netherlands, with prevalence rates ranging from $20 \%$ to $40 \%$ of restraint in the residences ${ }^{(6-7,18-19)}$. Therefore, despite the growing evidence of the negative impact of restraint measures ${ }^{(20-21)}$, the use of physical restraints was a common practice in the households visited. 


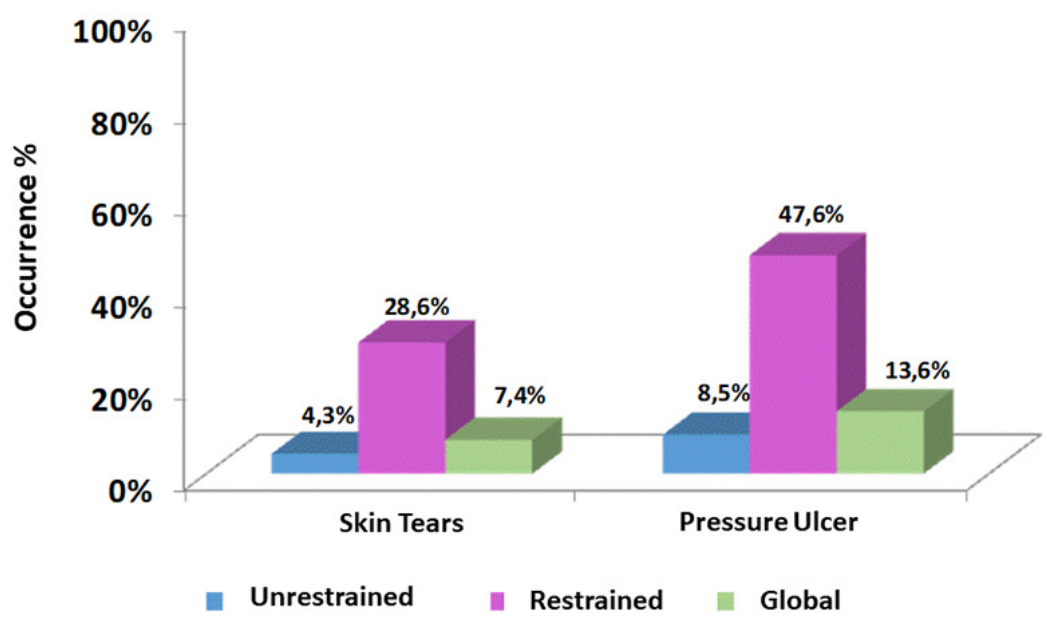

Figure 1 - Occurrence of Skin tear and Pressure Ulcer in the group of unrestrained elderly, restrained elderly and global. Rio de Janeiro, 2018

Source: Research data, 2018.

Brazilian studies carried out in a hospital environment showed a prevalence rate of mechanical restraints of $51.4 \%$, a percentage higher than the one found in the home environment, and the use of bed side rails was the main characteristic - unlike the home environment where rails were the $4^{\text {th }}$ type of restraint mentioned ${ }^{(12-14)}$. On the other hand, in a study carried out in long-term care facilities for elderly (LTCF), 7.34\% of patients were subjected to restraint measures in the hospitals visited. A comparison of the data obtained in the present study shows that the rate of mechanical restraint in the home environment is higher than that found in the 14 LTCFs investigated in the State of Rio de Janeiro ${ }^{(19)}$.

Regarding the characteristics of the restraint, bandage was the material with the highest prevalence of use, followed by sheets and tissues in general and, finally, rails. These results differ from those found in the Brazilian study in the hospital setting, according to which rails were the most prevalent material used in restraints ${ }^{(18)}$. However, in the hospital scenario, the use of the rails is even considered one of the criteria for hospital accreditation in protocols to prevent falls $s^{(10-15)}$. On the other hand, the presence of a hospital bed was not very frequent in the households visited. The reasons for this may be related to the high cost of acquisition and maintenance of these beds in Brazil, as well as to the fact that rooms with small doors may not allow sufficient space for circulation of people and access for hospital beds. These various reasons may therefore have influenced the primary choice for improvised materials and devices that are easily accessible or inexpensive for restraint.
The use of informally adapted materials for restraint, such as torn sheets and other tissues, belts, and tissues with ropes, or wooden or adapted metal rails were also described in the study in LTCF (19). These makeshift restraints can cause injuries to the elderly. For this reason, guidance to family members is of paramount importance, through a non-punitive dialogue that explains the risks and presents alternatives to mechanical restraint that should be used in home visits.

Such informality can further increase the risks inherent in the practice of mechanical restraint. The reason for this is that the pertinent foreign literature cites several injuries as complications arising from the use of mechanical restraint, by means of devices placed close to the patient's body, either correctly or improperly. The aforementioned injuries include brachial plexus injuries, delirium, death, immobility, incontinence, pressure ulcer, decreased muscle strength, pneumonia, urinary tract infection, physical deconditioning, joint contractures and psychological stress ${ }^{(17,20)}$.

Regarding the justifications for containing aggression, the findings of this study corroborate those of another study carried out in Rio de Janeiro, which addressed the main difficulties experienced by the caregiver of an elderly person with Alzheimer's Disease ${ }^{(15,19-20)}$; and a study conducted in Quebec that showed that $51 \%$ of the elderly are restrained because of factors associated with aggressive behavior involving physical aggression ${ }^{(15-21)}$; despite records that the use of restraint causes greater immobility, incontinence, pressure ulcer, depression, agitation, aggressiveness and mortality of elderly individuals ${ }^{(13,16)}$. 
This percentage suggests that aggressiveness is one of the main difficulties faced by non-professional, domestic and professional caregivers, and it occurs concomitantly with family relationships and the private world, with power relationships, with communication difficulties, with limited training of caregivers for clinical evaluation of pain, infection, discomfort.

It should be mentioned that medical monitoring and diagnosis, medication adjustment and other clinical issues such as infections, pain and even delirium can cause or increase aggressiveness, which makes elderly care more complicated and increases the risk of use of restraint measures $^{(21)}$. However, the present study did not address the training of professionals who work in home care, nor the evaluation of aggressive elderly patients. Therefore, there is no knowledge of a correlation between the measured aggressiveness and the issues mentioned.

The justifications for the use of restraint to prevent the risk of falls appeared in the comparison with studies in the hospital environment (51.4\%) and with the LTCFs (7.3\%), which were also the most recurrent justifications. In Germany, 80\% of LTCF residents are restrained to prevent the risk of falls or to prevent injuries related to falls ${ }^{(19)}$, although evidence demonstrates that the reduction in the practice of mechanical restraint does not result in an increase in the number of falls, contributing, on the contrary, to its reduction ${ }^{(12)}$ and that restraining is directly related to physical and functional, psychological and social decline of the elderly ${ }^{(21)}$.

Another alarming result is the amount of time elderly individuals are restrained at home. It was found that $42.9 \%$ of the elderly are contained 24 hours a day. Therefore, it is necessary to reflect on the quality of life offered to these individuals. And, again, it is necessary to disseminate consistent guidelines in order to resolve the factors that trigger restraint, allowing its use only for the time strictly necessary to resolve a critical and acute situation.

Regarding gerontogeriatric tests, it can be inferred that elderly people in home care are characterized by frailty, dependence on others for Activities of Daily Living (Katz Index) and cognitive loss (MMSE), that is, they are vulnerable elderly people. Other authors also claim that functionality, not age or gender, is the factor that influences the practice of mechanical restraint in the elderly ${ }^{(12-17)}$.

Likewise, the association data indicate possible risk factors that deserve to be investigated longitudinally to infer causality, and that are consistent with the profiles that demonstrate dependent elderly and with high demand for care, and poor environmental structure associated with the outcome of restraint of elderly who do not walk, are under permanent bladder catheterization and confined to bed. This can be explained by the presence of caregivers on alternate days, but also by the strong bonds established between dependent elderly and their family caregivers, ant the latter can have a great influence on the decision on mechanical restraint. It should be noted that home care tends to increase and consequently the number of dependent elderly.

Therefore, vulnerable elderly who demand more care in a home environment unsuitable for the provision of care or that even lacks human resources to ensure continuity of care are among those most at risk of being subjected to restraint practices. The indiscriminate use of mechanical restraint can repress wishes, desires and the dignity of individuals, frequently triggering adverse events. Then, the purposes of home care are not observed, as reintegration into the family environment should provide comfort and dignity to improve the quality of life of the elderly.

Thus, to effectively improve the quality of life of the elderly, it is important to improve home care, with family support services, providing training to formal and family caregivers, since restraint is often the result of iatrogenic care, ignorance, stress and tiredness of the caregiver, and of a hospital-centered home care service.

The present study found that restraint is prevalent in home care. However the limitations of the study such as prior contact by phone to schedule the visits by SIAD office; participation of the caregivers course annually promoted by the sector, which mentions the importance of the theme, and the fact that home visits were made only in the morning may have influenced the data. It is possible that a higher prevalence would be obtained if the restraints were measured at other times of the day and night, without prior notification. It should also be noted that mechanical restraint was only measured in patients restrained at the time of the interview. Thus, there is a temporal bias, and investigation at different times is recommended.

\section{Q CONCLUSIONS}

Given the relevant prevalence found in the study and the significance of the factors associated with the practice of mechanical restraint, home health care professionals, formal and informal caregivers should be trained, in order to denaturalize the practice of restraint, which aggravates the health of the elderly, dependence, skin injuries and demand for care. Therefore, it is recommended that rehabilitative home care practices be encouraged to preserve the autonomy of the elderly, giving them dignity, according to gerontological and home care principles. 


\section{REFERENCES}

1. Menezes AK, Santana RF, Cimador F. Práticas assistenciais restritivas e 0 paradigma da cultura de não contenção da pessoa idosa. In: Freitas EV, Py L, editores. Tratado de geriatria e gerontologia. Rio de Janeiro: Guanabara Koogan; 2016. p. 1267-76.

2. Farina-Lopez E, Estévez-Guerra GJ, Polo-Luque L, Pogrányivá AH, Penelo E. Physical restraint use with elderly patients: perceptions of nurses and nursing assistants in Spanish acute care hospitals. Rev Nurs Res. 2018;67(1):55-9. doi: https://doi.org/10.1097/NNR.0000000000000252

3. Heeren P, Detroyer E, Milisen K. Delirium, restraint use and falls. In: MonteroOdasso M, Camicioli R, editors. Falls and cognition in older persons. Cham: Springer; 2019 [cited 2019 0ct 20]. p 229-43. Available from: https://link. springer.com/chapter/10.1007\%2F978-3-030-24233-6_13

4. Castaldo A, Giordano A, Incalzi RA, Lusignani M. Risk factors associated with accidental falls among Italian nursing home residents: a longitudinal study (FRAILS). Geriatr Nurs. 2020;41(2):75080. doi: https://doi.org/10.1016/j. gerinurse.2019.06.003

5. Rajão FL, Martins M. Home Care in Brazil: an exploratory study on the construction process and service use in the Brazilian Health System. Ciênc Saúde Coletiva. 2020;25(5):1863-77. doi: https://doi. org/10.1590/1413-81232020255.34692019

6. Estévez-Guerra GJ, Fariña-Lopez Emilio, Nuñez-González E, Gandoy-Crego M, Calvo-Francés F, Capezuti EA. The use of physical restraints in long-term care in Spain: a multi-center cross-sectional study. BMC Geriatrics. 2017;17:29. doi: https://doi.org/10.1186/s12877-017-0421-8

7. Nakanishi M, Okumura Y, Ogawa A. Physical restraint to patients with dementia in acute physical care settings: effect of the financial incentive to acute care hospitals. Int Psychogeriatr. 2017;30(7):991-1000. doi: https://doi. org/10.1017/S104161021700240X

8. Scheepmans K, Casterlé BD, Paquay L, Van Gansbeke H, Boonen S, Milisen K. Restraint use in home care: a qualitative study from a nursing perspective. BMC Geriatr. 2014 [cited 2019 0ct 20];14:17. doi: https://bmcgeriatr.biomedcentral. com/articles/10.1186/1471-2318-14-17

9. Scheepmans K, Milisen K, Vanbrabant K, Paquay L, Gansbeke HV, Casterlé $B D$. Factors associated with use of restraints on older adults with home care: a secondary analysis of a cross-sectional survey study. Int J Nurs Stud. 2019;89:39-45. doi: https://doi.org/10.1016/j.ijnurstu.2018.07.019

10. Scheepmans K, Casterlé BD, Paquay L, Milisen K. Restraint use in older adults in home care: a systematic review. Int J Nurs Stud. 2018;79:122-36. doi: https:// doi.org/10.1016/j.jinurstu.2017.11.008

\section{- Conflict of interest:}

There is no conflict of interest

\section{- Corresponding author:}

Rosimere Ferreira Santana

E-mail: rosifesa@gmail.com
11. Kurata S, Ojima T. Knowledge, perceptions, and experiences of family caregivers and home care providers of physical restraint use with home-dwelling elders: a cross-sectional study in Japan. BioMed Central Geriatrics. 2014 [cited 2019 Oct 20];14:39. Available from: https://bmcgeriatr.biomedcentral.com/ articles/10.1186/1471-2318-14-39

12. Bleijlevens MHC, Wagner LM, Capezuti E, Hamers, JPH, International Physical Restraint Workgroup. Physical restraints: consensus of a research definition using a modified Delphi technique. J Am Geriatr Soc. 2016;64(11):2307-10. doi: https://doi.org/10.1111/jgs.14435

13. Santana RF, Capeletto CSG, Souza LMS, Menezes AK, Delvalle R, Souza MV. Contenção mecânica de idosos na atenção domiciliary: revisão de literatura. Estud Interdiscipl Envelhec. 2019 [cited 2019 Oct 10];24(2):29-43. Available from: https://seer.ufrgs.br/RevEnvelhecer/article/view/78426

14. Eskandari F, Abdullah KL, Zainal NZ, Wong LP. Use of physical restraint: nurses' knowledge, attitude, intention and practice and influencing factors. J Clin Nurs. 2017;26(23-24):4479-88. doi: https://doi.org/10.1111/jocn. 13778

15. Jiang H, LiC, HeY. Nurses'perceptions and practice of physical restraint in China. Nurs Ethics. 2015;22(6):652-60. doi: https://doi.org/10.1177/0969733014557118

16. Ye J, Xiao A, Yu L, Wei H, Wang C, Luo T. Physical restraints: an ethical dilemma in mental health services in China. Int J Nurs Sci. 2018;5(1):68-71. doi: https:// doi.org/10.1016/j.jijnss.2017.12.001

17. Conselho Federal de Enfermagem (BR). Resolução no 427/2012. Normatiza os procedimentos da Enfermagem no emprego da contenção mecânica de pacientes. Brasília, DF: COFEN; 2012 [cited 2019 0ct 29]. Available from: http:// www.cofen.gov.br/resoluo-cofen-n-4272012_9146.html

18. Souza LMS, Santana RF, Capeletto CSG, Menezes AK, Delvalle R. Fatores associados à contenção mecânica no ambiente hospitalar: estudo transversal. Rev EsC Enferm USP. 2019;53:e03473. doi: https://doi.org/10.1590/ s1980-220x2018007303473

19. Santana RF, Delvale R, Souza LMS, Menezes AK, Gabriel CS, Ferreira $T C B$, Melo UG. Mechanical containment in long-stay institutions for the elderly. Rev Enferm UFPE. 2018;12(12):3394-400. doi: https://doi. org/10.5205/1981-8963-v12i12a234527p3394-3400-2018

20. Cleary K, Prescott K. The use of physical restraints in acute and long-term care: an updated review of the evidence, regulations, ethics, and legality. J Acute Care Phys Ther. 2015;6(1):8-15. doi: https://doi.org/10.1097/ JAT.0000000000000005

21. Lan SH, Lu LC, Lan SJ, Chen JC, Wu WJ, Chang SP, Lin LY. Educational intervention on physical restraint use in long-term care facilities - systematic review and meta-analysis. Kaohsiung J Med Sci. 2017; 33(8):411-21. doi: https://doi. org/10.1016/j.kjms.2017.05.012

\section{Associate editor:}

Cíntia Nasi

Received: 11.16.2019

Approved: 07.13.2020

\section{Editor-in-chief:}

Maria da Graça Oliveira Crossetti 